\title{
Histopathological Evaluation of Soybean (Glycine max (L.) Merr.) Strains Resistance to Sclerotium rolfsii Disease
}

\author{
DOI: $10.18196 /$ pt.v10i1.8907
}

\author{
Siti Samiyarsih ${ }^{1^{*}}$, Chindy Ayu Erliana ${ }^{1}$, Juni Safitri Muljowati ${ }^{2}$, Nur Fitrianto ${ }^{3}$ \\ ${ }^{1)}$ Department of Botany, Faculty of Biology, Universitas Jenderal Soedirman \\ ${ }^{2}$ Department of Microbiology, Faculty of Biology, Universitas Jenderal Soedirman, Jalan Dr. Suparno No. 63 Purwokerto 53122, Banyumas, \\ Central Java, Indonesia \\ ${ }^{3)}$ Research and Technology Center for Application of Isotope and Radiation, National Research and Innovation Agency of Indonesia (BRIN); Jl. \\ Lebak Bulus Raya No. 49 Jakarta 12440, Indonesia. \\ *Corresponding author, email: siti.samiyarsih@unsoed.ac.id
}

\begin{abstract}
Sclerotinia infection of stem and leaf of soybean Glycine max (L.) Merr. caused by the fungal pathogen of Sclerotium rolfsii has recently become more important in the Indonesian soybean production area. This study aimed to evaluate the level of resistance and intensity of infection by $\mathrm{S}$. rolfsii in four soybean strains. The research was arranged in a factorial completely randomized design. The observed variables include the anatomy characteristics of leaves and stems of soybean and disease intensity caused by S. rolfsii. The data were analyzed quantitatively with the Analysis of Variance (ANOVA) at 95\% and 99\% confidence level, followed by the Least Significant Difference Test (Fisher's LSD) at the level of 5\%. Soybean leaves and stem anatomy inoculated by S. rolfsii showed a decrease in the stomatal density, epidermis thickness, and mesophyll thickness as well as a damaged cuticle, damaged stem epidermis, and swollen stem cortex. Four strains inoculated by S. rolfsii showed a higher disease intensity of 40\%-80\% compared to the resistant cultivar ('Dering') and susceptible cultivar ('Wilis'), showing disease intensity of $20 \%$ and $40 \%$, respectively.
\end{abstract}

Keywords: Glycine max, Histopathology, Resistance, Sclerotium rolfsii

ABSTRAK

Infeksi sclerotinia pada daun dan batang kedelai Glycine max (L.) Merr. yang disebabkan oleh jamur patogen Sclerotium rolfsii menjadi semakin penting di area produksi kedelai Indonesia. Penelitian ini bertujuan mengevaluasi tingkat resistensi dan tingkat intensits infeksi oleh S. roflsii terhadap empat galur kedelai. Metode yang digunakan dalam penelitian ini adalah metode eksperimen dengan pola rancangan acak lengkap pola faktorial. Parameter yang diamati meliputi karakteristik anatomi pada daun dan batang kedelai, dan intensitas penyakit yang disebabkan oleh S. rolfsii. Data dianalisis dengan Analisis Varians (ANOVA) dengan tingkat kepercayaan 95\% dan 99\%, analisis data dilanjutkan dengan Uji Beda Nyata Terkecil (LSD) 5\%. Karakteristik histopatologi daun dan batang yang diinokulasi oleh S. rolfsii menunjukkan adanya penurunan kerapatan stomata, ketebalan epidermis dan ketebalan mesofil, sekaligus menyebabkan kerusakan pada lapisan kutikula, epidermis batang, dan pembengkakan pada korteks batang. Empat galur yang diinokulasi oleh S. rolfsii memiliki intensitas penyakit yang lebih tinggi yaitu 40\% -80\% dibandingkan dengan kultivar 'Dering' sebagai kelompok tahan sebesar 20\% dan kelompok rentan pada kultivar 'Wilis' sebesar 40\%.

Kata kunci: Glycine max, Histopatologi, Resisten, Sclerotium rolfsii

\section{INTRODUCTION}

Soybean (Glycine max L.) is an important protein source plant in Indonesia. The increase of soybean production is in line with the increase in the number of population and industrial developments using soybean as raw materials. According to Wahyu (2013), soybean is one of the widely cultivated legume commodities in Indonesia. Due to the high consumption rate, efforts are needed to increase soybean production through superior cultivars. However, efforts to increase soybean production can not be separated from various obstacles, including pest and disease attacks. One of the acute diseases is stem rot disease caused by the Sclerotium rolfsii.

Histopathology based on leaves anatomy characters can be used as instructions to the structural resistance of plants against the pathogen (Samiyarsih et al., 2018). S. rolfsii is a fungus that can cause several diseases in plants, such as stem rot. A wilting disease caused by S. rolfsii is a common 
disease in soybean plants. This disease is often also referred to as stem rot disease or sclerotium rot because it causes root rot symptoms. S. rolfsii can also attack leaves, stems, and pods in soybean plants if conditions are very humid. Efforts to get high-yielding soybeans can pursue through plant breeding activities. Plant breeding is expected to improve and increase plants' genetic potential so that superior results are obtained with suitable characteristics, one of which is by selecting new strains (Wardoyo, 2009). Pure strain selection is made by choosing the best plants. Selected plants are individually harvested separately for planting material the following season. Cultivar differences in plants will provide genetically different responses (Sasongko et al., 2019).

The histopathology based on plants' anatomical structure plays an essential role in the relationship with pathogenic infections in tissues. The disease's effects cannot adequately be understood without understanding the typical structure of the affected tissue. Besides, the impact of disease or parasites and even susceptibility to disease can be identified by structural changes in the host structure's characteristics. The primary response of plants affected by fungal infections is structural defenses, such as cell wall thickness. The disease can prevent the penetration of pathogens into the host cell. Besides, pathogenic infections can cause the development of plant vascular tissue structures to be disrupted (Impullitti et al., 2014).

In this research, pure soybean strains were used to determine each different soybean strain's anatomical characteristics then compared to the cultivars. This study aimed to determine the differences in the anatomical character of leaves and stems in soybean strains that are resistant and susceptible to stem rot disease after inoculation with S. rolfsii and the level of intensity of attacks of each soybean strain used after S. rolfsii fungal infection.

\section{MATERIALS AND METHODS}

The research was conducted in June-September 2019 at the greenhouse, the Plant Structure and Development Laboratory, and the Mycology and Phytopathology Laboratory, Faculty of Biology, Jenderal Soedirman University, Puwokerto. This research was arranged in a completely randomized factorial design. The first level was four soybean strains (Strain no. 71-7, 39-6, 32-6, and 16-4) and two types of soybean cultivars ('Dering' and 'Wilis'). Soybean strains and cultivars are the collections of the Faculty of Agriculture, Jenderal Soedirman University. The second level was fungal inoculation treatment. Tests without inoculation and with fungal inoculation were carried out with five replications.

The isolates of S. rolfsii cultures were propagated in a potato dextrose agar (PDA) medium and incubated at room temperature for $5 \times 24 \mathrm{~h}$ (Astiko, 2009). Propagation of fungal inoculums was done using bran media as much as $3 / 4$ the volume of the bottle that had been sterilized first in the autoclave then inoculated with three plugs of rejuvenated fungal mycelium on PDA medium (Nugroho, 2008). The inoculation of S. rolfsii was carried out on the 14-day-old plant in the polybag. The inoculation of S. rolfsii was carried out by giving an inoculum at a depth of $\pm 1 \mathrm{~cm}$ between the plant's roots and on the soil surface.

Anatomical characteristics including cuticle, epidermis, mesophyll, stomata size, stomata, and trichomes density per $\mathrm{mm}^{2}$ area of the epidermis of leaves were observed using embedding methods of Khoiroh et al. (2014) and Samiyarsih et al. (2020a) with a slight modification. The $5^{\text {th }}$ leaf from the shoot bud was taken and cut into one-cm pieces. It was subjected to fixation in FAA solution (FAA: $10 \%$ formalin, $5 \%$ acetic acid, 50\% ethyl alcohol, and $35 \%$ distilled water) for $24 \mathrm{~h}$. Staining was done using safranin (1\%) in 70\% alcohol. Observa- 
tion of anatomical characteristics was performed using a binocular microscope Olympus $\mathrm{CH}-20$ (Damayanti, 2007). The incubation period was from the first day after the inoculation of pathogenic fungi until the disease's symptoms appeared. Observation of disease intensity was carried out to determine the level of resistance of soybean plants to stem rot disease. Consideration of the severity of the disease was carried out 15 days after planting. The percentage of disease intensity could be calculated using the formula of $\mathrm{I}=\mathrm{N} / \mathrm{n}$ $\times 100 \%$, in which $\mathrm{I}$ is the severity of the disease, $\mathrm{n}$ is the number of plants showing symptoms, and $\mathrm{N}$ is the number of plants observed. Disease intensity calculation results were then categorized based on the assessment of the level of resistance (Disease intensity (\%) resistance: $0-20=$ high; $>20-30=$ medium, and $>30=10 w)$. All data were analyzed by ANOVA followed by Least Significant Difference (LSD) test at 0.05 (5\%).

\section{RESULTS AND DISCUSSION}

Leaves Histopathological Characteristics of Soybean Strains Affected by S. rolfsii

The histopathology of soybean leaves that were attacked by S. rolfsii causing stem rot disease in the 'Dering' and 'Wilis' cultivars and four soybean strains with strain numbers $71-7$; 39-6; 32-6; and 16-4 showed the similar leaf anatomical structure (Table 1; Figure 1). The plant inoculated by S. rolfsii was damaged in the leaf epidermis and leaf mesophyll tissue. Meanwhile, a reduced palisade density characterized damage to the mesophyll tissue, and the space between cells contained in spongy tissue or sponges had also become more extensive. The strain no. 39-6 showed the least tissue damage compared to other strains and cultivars.

The highest thickness of the epidermis was observed in strain number 39-6, with a thickness of the adaxial and abaxial epidermis of 10.1 and $9 \mu \mathrm{m}$, respectively. Meanwhile, the highest meso-

Table 1. Histopathological characteristics of leaves and stem caused by S. rolfsii disease

\begin{tabular}{|c|c|c|c|c|c|c|c|c|c|}
\hline No & Cultivar/Strain & $\begin{array}{l}\text { Adaxial } \\
\text { epidermis } \\
\text { thickness }\end{array}$ & $\begin{array}{c}\text { Abaxial } \\
\text { epidermis } \\
\text { thickness }\end{array}$ & $\begin{array}{l}\text { Mesophyll } \\
\text { thickness }\end{array}$ & $\begin{array}{c}\text { The } \\
\text { adaxial } \\
\text { density of } \\
\text { stomata }\end{array}$ & $\begin{array}{l}\text { The abaxial } \\
\text { density of } \\
\text { stomata }\end{array}$ & $\begin{array}{l}\text { The abaxial } \\
\text { density of } \\
\text { trichomes }\end{array}$ & $\begin{array}{l}\text { The abaxial } \\
\text { density of } \\
\text { trichomes }\end{array}$ & $\begin{array}{c}\text { Stem } \\
\text { diameter }\end{array}$ \\
\hline 1 & Dering & $9.05 \mathrm{c}$ & $9.30 \mathrm{abc}$ & $58.65 \mathrm{~d}$ & $5.40 \mathrm{a}$ & $8.40 b c$ & $5.40 \mathrm{a}$ & $8.40 \mathrm{bc}$ & $2597.4 \mathrm{~b}$ \\
\hline 2 & Wilis & $8.50 c$ & $8.50 \mathrm{~cd}$ & $57.00 \mathrm{~d}$ & $4.92 a b$ & $7.72 b c$ & $4.92 a b$ & $7.72 \mathrm{bc}$ & $2524.8 b$ \\
\hline 3 & Strain no. 71-7 & $8.60 c$ & $8.25 \mathrm{~d}$ & $61.95 \mathrm{~d}$ & $4.96 \mathrm{ab}$ & $8.36 b c$ & $4.96 a b$ & $8.36 b c$ & $3089.8 \mathrm{a}$ \\
\hline 4 & Strain no. 39-6 & $10.50 \mathrm{a}$ & $10.10 \mathrm{a}$ & $95.90 \mathrm{~b}$ & $5.16 a b$ & $10.00 \mathrm{a}$ & $5.16 a b$ & $10.00 \mathrm{a}$ & $2652.0 \mathrm{~b}$ \\
\hline 5 & Strain no. 32-6 & $10.10 a b$ & $9.50 \mathrm{ab}$ & $73.60 \mathrm{c}$ & $4.54 b$ & $8.96 \mathrm{ab}$ & $4.54 b$ & $8.96 \mathrm{ab}$ & $2483.0 \mathrm{~b}$ \\
\hline 6 & Strain no. 16-4 & $9.25 b c$ & $8.85 \mathrm{bcd}$ & $104.30 \mathrm{a}$ & $3.86 \mathrm{c}$ & $7.30 \mathrm{c}$ & $3.86 \mathrm{c}$ & $7.30 \mathrm{c}$ & $2496.8 b$ \\
\hline
\end{tabular}

Remarks: Values followed by the same letters are not significantly different according to LSD at 5\%.

phyll thickness was found in strain number 16-4 $(103.7 \mu \mathrm{m})$, and the lowest mesophyll thickness was in the 'Wilis' cultivar $(48.6 \mu \mathrm{m})$. The highest number of adaxial epidermal stomata was in strain number 39-6 $\left(5.16 / \mathrm{mm}^{2}\right)$, and the lowest was in strain number $16-4\left(3.24 / \mathrm{mm}^{2}\right)$. The same results were obtained in the number of lower epidermal stomata. The highest and lowest number of lower epidermal stomata was observed in strain number $39-6\left(10.16 / \mathrm{mm}^{2}\right)$ and strain number $16-4$ (6.44/ $\mathrm{mm}^{2}$ ), respectively. There was significant difference in the number of adaxial and abaxial epidermal stomata (Figure 1). Kouwenberg et al. (2004) noted that morphogenesis changes caused variations in stomatal density between plants of various dicotyledonous plant species. Environmental adaptation factors can also influence the calculation of the number of stomata. Juwarno et al. (2017) reported that the adaxial and abaxial stomata density was not significantly different between soybean cultivars. 

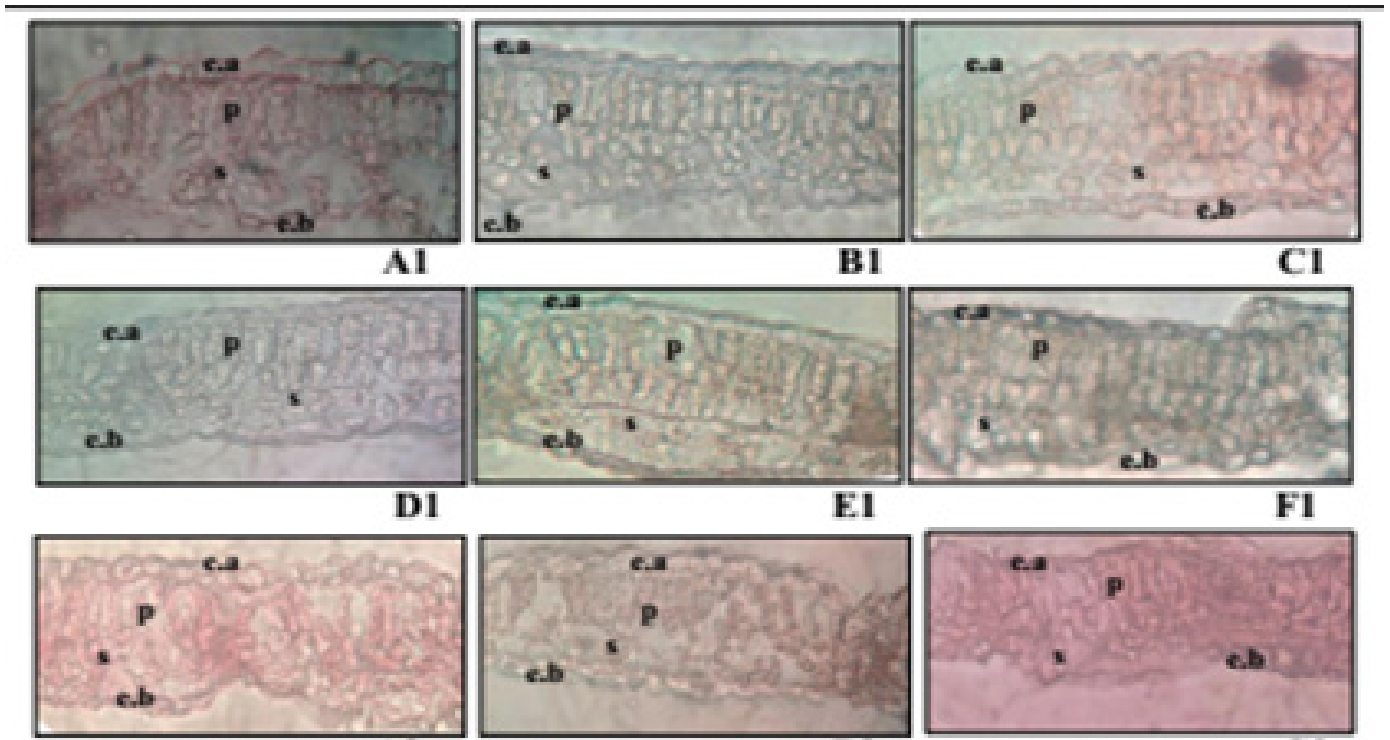

A2

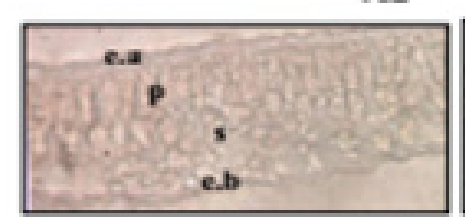

D2

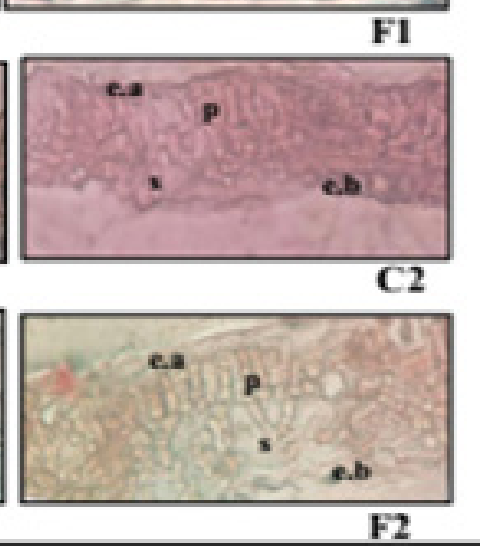

Figure 1. Leaves histopathology of soybean strains for resistance to $S$. rolfsii disease. Notes: A1-F1 (uninfected with S. roflsi); A2-F2 (Infected with S.roflsii); (A) Cultivar 'Dering'; (B) Cultivar 'Wilis'; (C) Strain no 71-7; (D) Strain no. 39-6;

(E) Strain no. 32-6; (F) Strain no. 16-4; (e.a) adaxial epidermis ; (p) palisade; (s) sponges; (e.b) abaxial epidermis.

The density of trichomes indicated less intensity of leaf damage. Based on different test tables, strain no. 39-6 showed similar average number of stomata to the resistant cultivar 'Dering'. Meanwhile, strain no. 32-6 and strain no. 16-4 hade lower number of stomata compared to the susceptible cultivar 'Willis'. The average number of trichomes in the upper epidermis was less than that of the lower epidermis. Wijaya (2016) states that the difference in the number and length of trichomes on the adaxial and abaxial surfaces of leaves is influenced by plant genetic factors to prevent pests and diseases that usually attack through the underside of the leaves. Arifin (2013) adds that the number of trichomes in healthy soybean plants is higher more than in sick soybean plants. Pradana et al. (2017) reported that the density of stomata-trichomes was the same as the plant disease intensity. On the other hand, Samiyarsih et al. (2020b) mention that soybean cultivars that have thicker cuticle and epidermis, high trichomes and low stomatal density, and low stomatal conductance have better anatomical resistance to leaf rust disease.

The lowest thickness of the upper epidermis was found in the 'Wilis' cultivar $(5.8 \mu \mathrm{m})$, but the lowest epidermis thickness was observed in the strain 71-7 $(6 \mu \mathrm{m})$. Decreased epidermal thickness is thought to occur as a result of changes in cell permeability in response to pathogens. Sastrahidayat (1989) summarized that reduced cell permeability was the beginning of changes in diseased tissue. The cells in the tissue that is attacked and damaged often undergo plasmolysis. Besides, the decrease in plants' epidermal thickness inoculated with S. rolfsii can also be caused by chemicals during preparations. Diseased plant tissue is more easily damaged when given treatment using chemicals. According to Samiyarsih et al. (2018), disease-resistant plants 


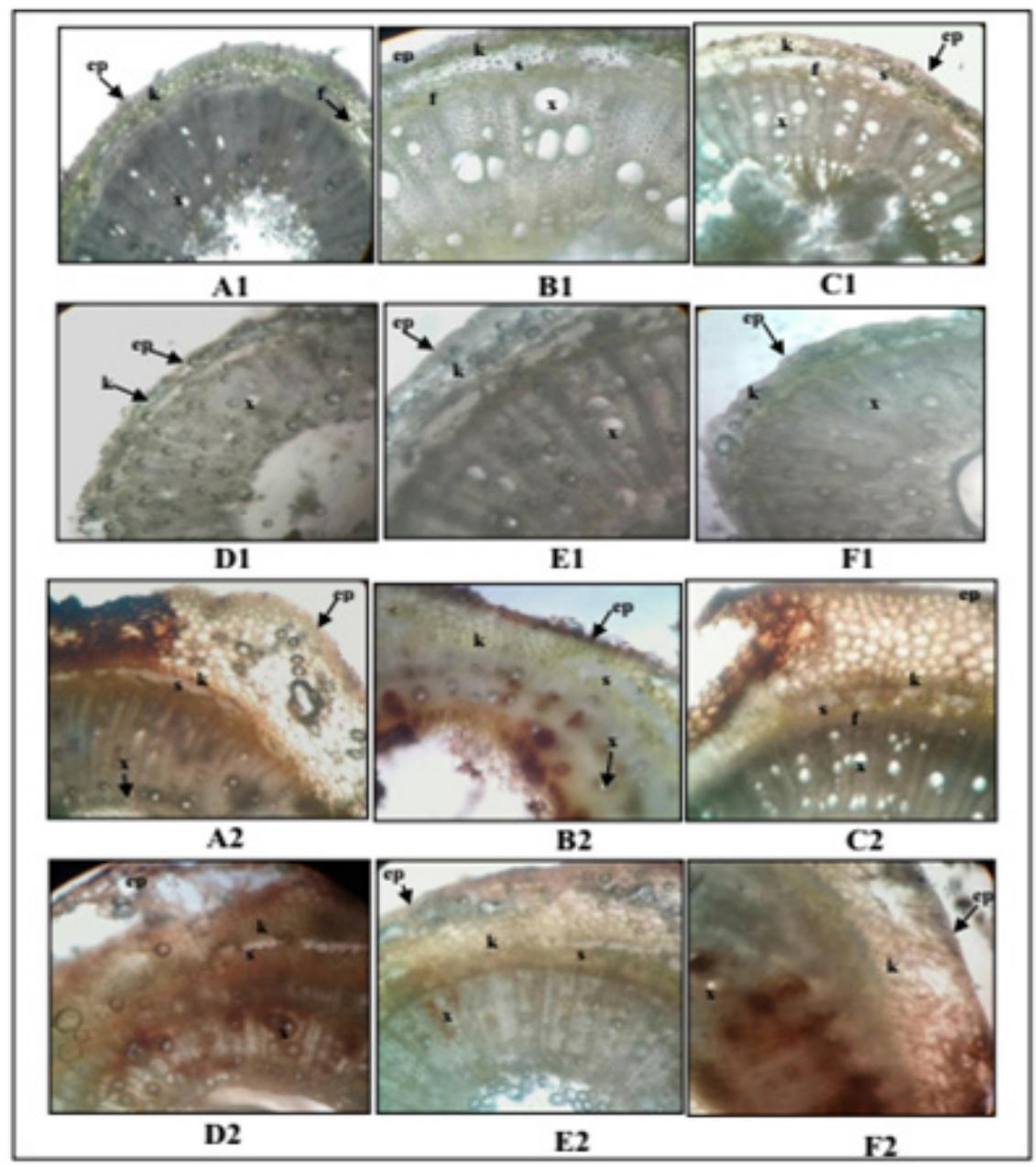

Figure 2. Stems histopathology of soybean strains for resistance to S. rolfsii disease. Notes: A1-F1 (uninfected with S. roflsii); A2-F2 (Infected with S.roflsii); (A) Cultivar 'Dering'; (B) Cultivar 'Wilis'; (C) Strain no 71-7; (D) Strain no. 39-6; (E) Strain no. 32-6; (F) Strain no. 16-4; (e.a) adaxial epidermis ; (p) palisade; (s) sponges; (e.b) abaxial epidermis.

tend to have thick epidermis, playing an essential of the stem to be swollen before finally decaying. role in inhibiting pathogens penetration into host Phenol accumulation also occurs, causing the stem cells. to turn brown. Changes in metabolism in diseased

Stem Diameter of Soybean Strains Affected by S. rolfsii

Strain number 71-7 were significantly different from the cultivar 'Dering,' cultivar 'Wilis,' strain number 39-6, strain number 32-6, and strain no. 16-4. Other than strain numbers 71-7, the other strains and cultivars had uniform stem size (Figure 2). Stems infected with S. rolfsii showed a more brownish color. The color is due to the attacks of S. rolfsii to the stem's base, causing the bottom plants accompany an increase in respiration after infection because the enzymes associated with respiration increase. Tang et al. (2015) reported that S. rolfsii produced a variety of extracellular enzymes, including pectin methylesterase, cutaneous, phosphatides, arabanase, gateringase, mannanase, xylanase, oxalic acid, and polygalacturonase, which are thought to cause tissue death along with mycelial growth during the infectious process.

The stem diameter of the cultivar 'Dering' inoculated with S. rolfsii had a larger size than that 


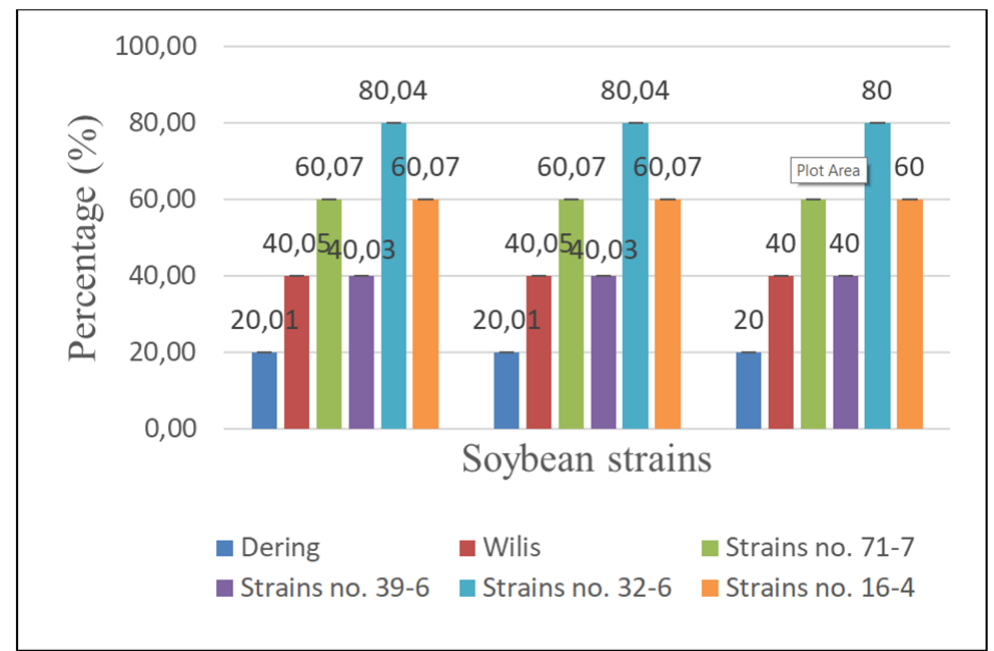

Figure 3. Percentage of disease intensity of soybean strains against S. rolfsii (in three replication).

of the cultivar 'Dering' without inoculation. This is related to the swollen stems of plants after the inoculation of S. rolfsii. It was characterized by an enlarged size of the cortex of stems infected with $S$. rolfsii due to disruption of nutrient absorption by xylem and phloem compared to stems uninfected with S. rolfsii. The cortex's internal part is a system of stem vessels consisting of the phloem on the outside and xylem. Another factor that is thought to have an influence is the swollen cell wall, which increases diameter. Direct penetration occurs in the epidermis cell wall by a pathogen, and sometimes the outer cell wall will be swollen, thereby inhibiting pathogen penetration. The results of the analysis of the variety of soybean stem diameters showed very significant values. Pranita et al. (2010) investigated that in stems experiencing secondary growth, the epidermal layer is replaced by a cork layer formed from cork cambium. The cork layer in plants helps increase the protective power of the stem and reduce water evaporation.

\section{Pathogenicity of S. rolfsiit to soybean strains and cultivars}

The pathogenicity test results on soybean revealed that S.rolfsii fungi were capable of infecting test plants, including the 'Dering' cultivar, 'Wilis' cultivar, strain no. 71-7, strain no. 39-6, strain no.
32-6, and strain no. 16-4. 'Dering' cultivar showed the lowest disease intensity value of $20 \%$. 'Wilis' cultivar and line no. 39-6 had the same disease intensity value, equal to $40 \%$, and strain no. $71-7$ showed a disease intensity of $60 \%$. Meanwhile, the highest disease intensity was found in strainno-32-6, which is $80 \%$ (Figure 3). The disease intensity of 'Dering' cultivar showed a high level of disease resistance. Meanwhile, the 'Wilis,' S. rolfsii cultivar, strain no. 71-7, strain no. 39-6, line 32-6, and line no. 16-4 are categorized as low resistance.

In soybean plants, the symptom is the start of the withering of soybean plants, accompanied by the stems' base that begins to rot. The incubation period for S. rolfsii pathogens in test plants ranged from three to nine days. Environmental factors provide a considerable influence for pathogens to infect soybean plants. Environmental conditions due to routine watering in the morning and evening cause the soil around the stems to become more humid. This is undoubtedly beneficial for the breeding of S. rolfsii spores. Sumartini (2011) reported that the $S$. rolfsii would be more infective at high humidity, causing high intensity and extent of the attack. Conversely, low moisture would stimulate S. rolfsii to form sclerotia.

The novelty of selecting soybean germplasm 
against biotrophic fungal disease is essential and effective in order to increase crop productivity (Samiyarsih et al., 2020b). Overall, the level of resistance in the four strains observed is relatively low. This is due to the high intensity of disease in the four strains compared to cultivars that have been released, which is above 30\%. The higher the intensity of the disease, the lower the resistance to pathogens. Astiko et al. (2009) stated that there were differences in resilience plants among soybean varieties in suppressing the development of rot disease stem base. Each strain has different resistance characteristics to $S$. rolfsii attacks due to the different resistance genes controllers to fight pathogens in each variety.

\section{CONCLUSION}

The difference in disease intensity of soybean strains and cultivars tested is greatly influenced by plant resistance. Histopathological evaluation of soybean leaves inoculated by S. rolfsii showed decreased leaf epidermis thickness and leaf mesophyll thickness, as well as damage to the cuticles, stem epidermis, and swollen cortex of the stem. All Strains inoculated with S. rolfsii showed a higher disease intensity of $40 \%-80 \%$ compared to the resistant cultivar 'Dering' (20\%), and the susceptible cultivar 'Willis' (40\%). This method is helpful in differentiating reactions of soybean strain or cultivars to S. rolfsii.

\section{REFERENCES}

Arifin, A. S. (2013). Kajian Morfologi Anatomi dan Agronomi antara Kedelai Sehat dengan Kedelai Terserang Cowpea Mild Mottle Virus serta Pemanfaatannya sebagai Bahan Ajar Sekolah Menengah Kejuruan. Jurnal Pendidikan Sains, 1(2), pp. 115-125.

Astiko, W., Muthahanas, l., \& Fitrianti, Y. (2009). Uji Ketahanan Beberapa Kultivar Kacang Tanah Lokal Bima Terhadap Penyakit Sclerotium rolfsii Sacc. Crop Agro, 5(1).

Damayanti, F. (2007). Analisis Jumlah Kromosom dan Anatomi Stomata pada Beberapa Plasma Nutfah Pisang (Musasp.) Asal Kalimantan Timur. Journal of Bioscientiae. 4(2), pp. 53 - 61.

Impullitti, A. E \& Malvick, D. K. (2014). Anatomical Response and
Infection of Soybean during Latent and Pathogenic Infection by Type A and B of Phialophora gregata. PLOS ONE, 9(5), pp.1-11. Juwarno, J., \& Samiyarsih, S. (2017). Anatomical and Molecular Responses of SoyBean (Glycine Max (L.) Merr.) Due to Salinity Stresses. Molekul, 12(1): 45-52.

Khoiroh Y, Harijati N \& Retno M. (2014). Pertumbuhan Serta Hubungan Kerapatan Stomata dan Berat Umbi pada Amorphophallus muelleri Blume. \&Amorphopallus variabillis Blume. Jurnal Biotropika. 2 (5): 249-253.

Kouwenberg, L. L. R., Kurschner, W. M., \& Visscher, H. (2004). Changes in Stomatal Frequency and Size During Elongation of Tsuga Heterophylla Needles. Annals of Botany, 94, pp. 561-569. Nugroho, B. A. (2008). Cara Membuat Media Tumbuh dalam Pengembangan Massal APH Golongan Jamur. Surabaya: POPT BBP2TP.

Pradana, A. W., Samiyarsih, S., \& Muljowati, J. S. (2017). Korelasi karakter anatomi daun ubi jalar (Ipomoea batatas L.) kultivar tahan dan tidak tahan terhadap intensitas penyakit kudis daun. Scripta Biologica, 4(1), 21-29.

Pranita, R., Y. R. Fitri, T. Asneti, Juwilda, E. F. Zeba. (2010). Epidermis Pada Tumbuhan Makalah. Universitas Sriwijaya: Inderalayah.

Samiyarsih S, Fitrianto N, Azizah E, Herawati W, Rochmatino. (2020a). Anatomical profile and genetic variability of sweet potato (Ipomoea batatas) cultivars in Banyumas, Central Java, based on RAPD markers. Biodiversitas 21(4): 1755-1766.

Samiyarsih, S., Pratiwi, A. Y. P., Muljowati, J. S., \& Fitrianto, N. (2020b). Selection of Soybean (Glycine max) Germplasm Against Biotrophic Fungi Disease Based on Anatomical Resistance. Biosaintifika: Journal of Biology \& Biology Education, 12(3): 311-318. Sasongko ND, Samiyarsih S, Juwarno. (2019). Genetic variation among the scabies-infested sweet potato cultivars. Intl J CurrRes 11 (7): 5115-5120.

Sumartini. (2011). Penyakit Tular Tanah (Sclerotium rolfsii dan Rhizoctonia solani) pada Tnaman Kacang-Kacangan dan UmbiUmbian Serta Cara Pengendaliannya. Jurnal Litbang Pertanian, 31(1), pp. 1-8.

Tang, Wei., Kuang, J., \& Qiang, S. (2015). The Pathogenicity of Sclerotium rolfsii on Cyperus difformis and its Potential Host Specificity among the Genus Cyperus. Journal Plant Pathology \& Microbiology, 8(3): 1-6.

Wahyu, E. R., Purwani, K. I., \& Nurhatika, S. (2013). Pengaruh Glomus fasciculatum Pada Pertumbuhan Vegetatif Kedelai yang Terinfeksi Sclerotium rolfsii. Jurnal Sains dan Seni POMITS, 2(2): 1-5.

Wardoyo, S. D. W. (2009). Uji Daya Hasil Lanjutan Galur-Galur Harapan Kedelai (Glycine max (L.) Merr.) Berdaya Hasil Tinggi. Skripsi. Fakultas Pertanian IPB. Bogor.

Wijaya, I., Zubaidah, S., \& Kuswantoro, H. (2016). Karakter Anatomi Galur-Galur Harapan Kedelai (Glycine max L. Merill) Tahan Cowpea Mild Mottle Virus (CpMMV). Jurnal Pendidikan Biologi Bioedukasi, 7(1): 16-25. 